Understanding Poverty 
Also by Pete Alcock

SOCIAL POLICY IN BRITAIN: Themes and Issues

POVERTY AND STATE SUPPORT

WELFARE LAW AND ORDER (with Phil Harris) 


\section{Understanding Poverty}

Second Edition

Pete Alcock

Consultant Editor: Jo Campling 


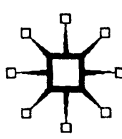

(C) Pete Alcock 1993, 1997

All rights reserved. No reproduction, copy or transmission of this publication may be made without written permission.

No paragraph of this publication may be reproduced, copied or transmitted save with written permission or in accordance with the provisions of the Copyright, Designs and Patents Act 1988, or under the terms of any licence permitting limited copying issued by the Copyright Licensing Agency, 90 Tottenham Court Road, London WIP OLP.

Any person who does any unauthorised act in relation to this publication may be liable to criminal prosecution and civil claims for damages.

The author has asserted his right to be identified as the author of this work in accordance with the Copyright, Designs and Patents Act 1988.

First edition 1993

Reprinted 1993, 1994, 1996

Second edition 1997

Published by

PALGRAVE

Houndmills, Basingstoke, Hampshire RG21 6XS and 175 Fifth Avenue, New York, N. Y. 10010

Companies and representatives throughout the world

PALGRAVE is the new global academic imprint of St. Martin's Press LLC Scholarly and Reference Division and Palgrave Publishers Ltd (formerly Macmillan Press Ltd).

ISBN 978-0-333-69280-6

DOI 10.1007/978-1-349-25666-2

This book is printed on paper suitable for recycling and made from fully managed and sustained forest sources.

A catalogue record for this book is available from the British Library.

$\begin{array}{rrrrrr}10 & 9 & 8 & 7 & 6 & \\ 06 & 05 & 04 & 03 & 02 & 01\end{array}$

Copy-edited and typeset by Povey-Edmondson Okehampton and Rochdale, England 
For Dan and Tom

Chris and Anna 


\section{Contents}

List of Figures and Tables $\quad$ xi

List of Abbreviations $\quad$ xii

Preface to the First Edition xiv

Preface to the Second Edition and Acknowledgements xvi

\section{PART I THE CONTEXT OF POVERTY}

1 What is Poverty? 3

Is Poverty a Problem? 3

Identifying Poverty 6

The History of Poverty 9

The Extent of Poverty 13

2 The Poor and the Underclass 19

Ideologies of Poverty 19

Who is Poor? 23

The Underclass $\quad 27$

The Legacy of Pathology 29

Cultural Divisions and the Poor 32

3 The Causes of Poverty 36

The Dynamics of Deprivation $\quad 36$

Pathological Causes $\quad 37$

Structural Causes $\quad 39$

Ideological Perspectives $\quad 43$

4 Poverty in Europe and Beyond 48

International Comparisons $\quad 48$

Poverty in Europe $\quad 50$

European Antipoverty Policy 56

Britain in Europe $\quad 61$ 


\section{PART II DEFINITION AND MEASUREMENT}

5 Defining Poverty 67

The Need for Definition $\quad 67$

Absolute and Relative Poverty $\quad 70$

Budget Standards $\quad 74$

Income Proxy Measures $\quad 77$

Deprivation Indicators $\quad 79$

Towards a Democratic Definition $\quad 83$

6 Deprivation and Social Exclusion $\quad 85$

Relative Deprivation $\quad 85$

Deprivation at Home and Work $\quad 88$

Social Exclusion $\quad 92$

Social Polarisation $\quad 96$

7 Households and Poverty Dynamics $\quad 99$

Indivduals and Households $\quad 99$

Household Size and Structure 100

Equivalence Scales 103

Intrahousehold Transfers 104

Poverty Dynamics 107

Life Cycle Changes 110

8 Measuring Poverty 114

The Problem of Measurement 114

Quantitative Measures $\quad 116$

Measuring Inequality 122

Qualitative Analysis $\quad 126$

\section{PART III SOCIAL DIVISIONS AND POVERTY}

9 Gender and Poverty 133

The Feminisation of Poverty 133

Employment and Low Pay 137

Social Security 141

The Costs of Caring $\quad 145$

Dependency 148

10 Racism and Poverty 151

Racism and Ethnic Minority Inequality 151 
Employment, Unemployment and Race 156

Racism and the Benefits System 157

Racism and Social Exclusion 162

11 Ageing and Poverty 165

Poverty and Dependency in Old Age 165

$\begin{array}{ll}\text { Retirement } & 168\end{array}$

Pensions $\quad 171$

$\begin{array}{ll}\text { The Social Construction of Dependency } & 177\end{array}$

12 Disability and Poverty 181

The Costs of Disability 181

Exclusion from Work $\quad 184$

Benefits and Dependency 186

Poverty for Carers $\quad 190$

Reproducing Deprivation in Disability 192

\section{PART IV THE POLICY FRAMEWORK}

13 The Politics of Poverty 197

The Arithmetic Tradition 197

The Poverty Lobby 201

Campaigning by the Poor 205

14 Social Security Policy 210

The Principles of Social Security 210

The Development of State Support 213

Social Insurance $\quad 217$

Social Assistance 221

Universal Benefits $\quad 225$

Problems with Benefits 227

Alternative Models for Social Security 230

15 Targeted Antipoverty Strategies 236

Pockets of Poverty 236

The War on Poverty 238

Government Antipoverty Initiatives $\quad 240$

Welfare Rights 243

Local Antipoverty Strategies $\quad 247$

Missing Targets 249 
16 Poverty, Inequality and Welfare 252

The Problem of Poverty 252

The Strategy of Equality

255

The Strategy of Inequality

258

Welfare State and Welfare Capitalism

261

References

266

Index

283 


\section{List of Figures and Tables}

Figures

1.1 Shares of disposable income, 1977-93 16

2.1 Individuals below half average income, 1961-91, by economic status

4.1 The distribution of poverty in Europe $\quad 54$

$\begin{array}{lll}5.1 & \text { The Engel curve } & 77\end{array}$

5.2 Inflection points on the Engel curve 78

5.3 Deprivation by logarithm of income as a percentage of SB rates

7.1 Income over the life cycle 107

8.1 Pen's 'Parade of Dwarfs' 123

$\begin{array}{ll}8.2 \text { The Lorenz curve } & 123\end{array}$

$\begin{array}{ll}8.3 & \text { Intersecting Lorenz curves } \\ & 125\end{array}$

\section{Table}

1.1 Rises in real income between 1979 and 1992/93 (including the self-employed) 


\section{List of Abbreviations}

$\begin{array}{ll}\text { AA } & \text { Attendance Allowance } \\ \text { CAB } & \text { Citizens' Advice Bureau } \\ \text { CB } & \text { Child Benefit } \\ \text { CDP } & \text { Community Development Project } \\ \text { CPAG } & \text { Child Poverty Action Group } \\ \text { DHSS } & \text { Department of Health and Social Security } \\ \text { DIG } & \text { Disablement Income Group } \\ \text { DLA } & \text { Disability Living Allowance } \\ \text { DSS } & \text { Department of Social Security } \\ \text { DWA } & \text { Disability Working Allowance } \\ \text { EAPN } & \text { European Antipoverty Network } \\ \text { EC } & \text { European Commission } \\ \text { EPA } & \text { Educational priority area } \\ \text { ERDF } & \text { European Regional Development Fund } \\ \text { ERM } & \text { Exchange rate mechanism } \\ \text { ESF } & \text { European Social Fund } \\ \text { EU } & \text { European Union } \\ \text { FC } & \text { Family Credit } \\ \text { FES } & \text { Family Expenditure Survey } \\ \text { FIS } & \text { Family Income Supplement } \\ \text { GLC } & \text { Greater London Council } \\ \text { HB } & \text { Housing Benefit } \\ \text { HBAI } & \text { Households below average incomes } \\ \text { ICA } & \text { Invalid Care Allowance } \\ \text { IEA } & \text { Institute of Economic Affairs } \\ \text { IFS } & \text { Institute for Fiscal Studies } \\ \text { IS } & \text { Income Support } \\ \text { LIF } & \text { Low income families } \\ \text { LIS } & \text { Luxembourg Income Study } \\ \text { LSE } & \text { London School of Economics } \\ \text { MA } & \text { Mobility Allowance } \\ \text { MSC } & \text { Manpower Services Commission } \\ \text { NA } & \text { National Assistance } \\ \text { NAB } & \text { National Assistance Board } \\ \text { NACAB } & \text { National Association of Citizens' Advice Bureaux } \\ \text { NCIP } & \text { Non-Contributory Invalidity Pension } \\ & \end{array}$


NI National Insurance

OECD Organisation for Economic Co-operation and Development

OEO Office of Economic Opportunity

OPCS Office of Population Censuses and Surveys

PSI Policy Studies Institute

SB Supplementary Benefit

SDA Severe Disablement Allowance

SERPS State Earnings Related Pensions Scheme 


\section{Preface to the First Edition}

What thoughtful rich people call the problem of poverty, thoughtful poor people call with equal justice a problem of riches $(\mathrm{R} . \mathrm{H}$. Tawney, 1913).

I set out to write a book about poverty in Britain with Tawney's famous words echoing in my mind. I felt that in one short sentence he had summed up the main issues involved in both the political and the definitional debates on poverty in modern society. After completing the task I had not changed my view on this; and if this book achieves the goals I set for it, it will be by explaining to those who are new to these debates, or to those who wish to revisit them, why Tawney was right eighty years ago and why today we are still struggling to come to terms with the implications of his analysis.

The title of the book expresses these goals. The book is intended as a textbook, providing students of social policy, sociology and related disciplines with an analysis of the various debates that have been conducted in Britain and beyond on the problem of poverty, and of the policies that have been developed in response to these. The book therefore discusses research on poverty carried out in Britain and elsewhere; but it is not a report of research and it is not itself based on any new or original research. As we shall see, especially in Part II, both existing research and the academic and political debates that flow from it involve major contradictions and conflicts of view - most fundamentally over the very meaning of the word poverty itself.

Academics and politicians have not come to an agreement what poverty is or what should be done about it. Indeed they frequently talk at cross purposes about the size and seriousness of the problem. What all are agreed on, however, is that poverty, where it does exist, is a problem, and a problem that requires policy responses to deal with it. This book is a guide to the various ways in which the problem of poverty has been defined and measured, and to the policies that have been developed in attempts to respond to it. It assumes some knowledge of the social science context of the debate on social phenomena, but presumes no prior acquaintance with writing on or research into 
poverty and related issues. I hope that the understanding that it provides is accessible and self-explanatory. What it does not provide, of course, is any simple answer to the problem itself - beyond that which is implicit in Tawney's early insights.

I should like to thank a few people who helped in the writing of the book. Saul Becker, at Loughborough, read through a first draft and provided helpful comments and suggestions, some of which I followed. Chris Pond of the Low Pay Unit acted as reader and offered many useful comments. Jo Campling encouraged me to begin a project that I had been thinking about for some time, and helped me to secure the publisher's interest in ensuring that it saw the light of day. Academics writing about poverty are often criticised for talking about the problem rather than doing something about it: writing this has not lessened my commitment to the latter, and I hope it might encourage that commitment in others too. 


\section{Preface to the Second Edition and Acknowledgements}

The second edition of this book is the product of significant revision and updating to reflect recent evidence on the developing problem of poverty in Britain and recent policy responses to this. The book has been revised throughout and many new references included. There has also been some restructuring, in particular the discussion of 'the underclass' has been moved alongside other material on the distribution of poverty, and there is a new chapter dealing directly with the causes of poverty. Other major changes include discussion of the now widely recognised and debated problems of social exclusion and social polarisation, a review of the importance of poverty dynamics in the measurement and definition of poverty, and brief coverage of the recent extensions to local antipoverty action in Britain.

New research evidence includes in particular the findings of the various projects involved in the Joseph Rowntree Foundation's Inquiry into Income and Wealth in the early 1990s. What this and other research depressingly confirms is that, in the short period between writing the first edition of this book and revising this for the second edition, the problem of poverty in Britain has continued to worsen rather than improve. It is to be hoped that any future editions might have a more uplifting story to tell.

Pete Alcock

The author and publishers wish to thank the following who have kindly given permission to use copyright material: John Hills and the Joseph Rowntree Foundation for Figures 1.1 and 2.1 from J.R. Foundation Inquiry into Income and Wealth, Vol. 2; London School of Economics and Political Science for Figure 4.1 from LSE/Welfare Programme Discussion Paper WSP/16 by A.B. Atkinson; Oxford University Press for Figures 8.2 and 8.3 from The Economics of Inequality by A. B. Atkinson, Figures 2.2 and 3.2, 1983.

Every effort has been made to trace all the copyright-holders, but if any have been inadvertently overlooked the publishers will be pleased to make the necessary arrangement at the first opportunity. 